Zeszyty Naukowe Szkoły Głównej Gospodarstwa Wiejskiego

Ekonomika i Organizacja Gospodarki Żywnościowej nr 111, 2015: 143-159

Izabela Sowa, Jolanta Zrałek

Katedra Badań Konsumpcji

Uniwersytet Ekonomiczny w Katowicach

\title{
Młodzi Polacy wobec wyzwań współczesnego rynku - wybrane zachowania i ich determinanty w latach 2004-2014
}

\section{Wstęp}

Zachowania młodych konsumentów od wielu lat są przedmiotem zainteresowania ekonomistów i osób zajmujących się marketingiem. Starają się oni zidentyfikować czynniki, które na nie wpływają i, na tej podstawie, przewidywać decyzje młodych konsumentów oraz dopasowywać do nich swoje działania marketingowe. W literaturze spotkać można wiele sposobów klasyfikacji determinant zachowań konsumenckich. Są wśród nich podziały na czynniki subiektywne i obiektywne, zewnętrzne i wewnętrzne, ekonomiczne i pozaekonomiczne, mierzalne i niemierzalne [Gajewski 1997, s. 20-23; Kramer 1997, s. 78-82; Garbarski 1998, s. 21-37; Kieżel (red.) 2000, s. 103-168]. Sposób oddziaływania poszczególnych determinant nie ma charakteru stałego - w różnych okolicznościach rola i znaczenie poszczególnych czynników rośnie lub maleje.

Badacze od dziesięcioleci próbują rozpoznać zachowania młodych konsumentów. Chareonsuk koncentrował się na zrozumieniu procesów zachodzących w okresie dojrzewania, Rammasoot badał wpływ środowiska, kultury, odżywiania i aktywności fizycznej na zachowania, a Satetoh wskazywał na różnice kulturowe między młodzieżą wiejską i miejską [Patanaittikul i Ongkrutraksa 2011, s. 57]. W Polsce badania nad tą grupą uczestników rynku prowadziła m.in. A. Olejniczuk-Merta [Olejniczuk-Merta 2001; Olejniczuk-Merta 2009]. Wszystkie te projekty badawcze odnosiły się jedynie do wybranych przejawów zachowań młodych konsumentów, ponieważ kompleksowa analiza wpływu wszystkich determinant nie byłaby możliwa. W niniejszym opracowaniu także skoncentrowano się na roli wybranych determinant (płci, wieku, miejsca zamieszkania, wy- 


\section{4}

sokości kieszonkowego oraz poziomu wykształcenia rodziców) w kształtowaniu zachowań konsumentów w wieku od 14 do 19 lat.

Celem artykułu jest wskazanie zmian, jakie zaszły w ostatnich 10 latach w zachowaniach młodych konsumentów, zidentyfikowanie wybranych czynników kształtujących te zachowania, a także wskazanie ich zmieniającej się roli. Badania bezpośrednie będące podstawą zawartych $\mathrm{w}$ artykule rozważań prowadzono w latach 2004, 2006 oraz 2014 wśród młodzieży I i III klas szkół gimnazjalnych i ponadgimnazjalnych województw: śląskiego, małopolskiego i łódzkiego.

\section{Istota zachowań konsumenckich}

Zgodnie z definicją G. Antonidesa i W.F van Raaija, ,zachowanie konsumenta obejmuje: czynności psychiczne i fizyczne (zachowanie) łącznie z ich motywami i przyczynami jednostek i (małych) grup dotyczące orientacji, kupowania, użytkowania, utrzymywania i pozbywania się wyrobu (cykl konsumpcji) oraz produkcji gospodarstwa domowego (zrób to sam) (rzadkich) towarów i usług $\mathrm{z}$ sektora rynkowego, sektora publicznego oraz sektora gospodarstwa domowego, pozwalające konsumentowi funkcjonować oraz osiagać swoje cele i urzeczywistniać wartości, a dzięki temu osiągać zadowolenie i dobrobyt z uwzględnieniem skutków krótko- i długofalowych oraz konsekwencji jednostkowych i społecznych" [Antonides i van Raaij 2003, s. 24]. Zaproponowana definicja akcentuje fakt, że konsumpcja jest nie tylko zaspokajaniem podstawowych potrzeb, ale obejmuje również działania mające przyczynić się do realizacji wartości oraz osiagania przez konsumenta satysfakcji i przyjemności. Zachowania konsumenta mogą zatem obejmować np. czynności związane z zagospodarowaniem czasu wolnego, konsumowaniem dóbr o charakterze symbolicznym. Takie definiowanie zachowań jest szczególnie uzasadnione na rynku młodych konsumentów, którzy samodzielne decyzje rynkowe zwykle podejmują w odniesieniu do tych produktów, których konsumpcja silnie determinowana jest przez czynniki o charakterze społecznym. Zaspokajanie potrzeb podstawowych i podejmowanie związanych z tym decyzji w większości przypadków spoczywa natomiast na rodzicach nastolatków.

Jednym z podstawowych podziałów determinant zachowań konsumentów jest wydzielenie czynników wewnętrznych oraz zewnętrznych (środowiskowych). Do pierwszej z tych grup należy zaliczyć zmienne wynikające z rozwoju fizycznego i intelektualnego konsumenta, jego osobowości, stylu życia oraz potrzeb. W szczególności wśród czynników wewnętrznych należy zatem wymienić percepcję, proces uczenia się, pamięć, potrzeby, osobowość, postawy, styl życia. 
Czynniki zewnętrzne obejmują wszystko to, co otacza konsumenta i ma wpływ na jego sposób myślenia oraz odczuwania, a także na podejmowane przez niego działania [Peter i Olson 2005]. Głównymi przykładami czynników zewnętrznych sa grupy odniesienia, rodzina, status społeczny, klasa społeczna, kultura i subkultury. Do czynników zewnętrznych należą także nowe trendy obserwowane w otoczeniu rynkowym konsumentów.

Percepcja oznacza proces, w ramach którego ludzie dokonują wyboru, interpretują i porządkują informacje. Proces uczenia się prowadzi do zmiany zachowań $\mathrm{w}$ reakcji na doświadczenie lub instynkt. Istotny wpływ na podejmowane decyzje ma także pamięć zarówno długotrwała, jak i krótka. Pamięć to właściwość organizmu (funkcja psychiki), polegająca na gromadzeniu i przechowywaniu ubiegłego doświadczenia oraz wykorzystywaniu go w różnych sytuacjach [Sowa 2010, s. 137].

Zarówno potrzeby, pragnienia i życzenia oznaczają różnice pomiędzy tym, co konsument postrzega jako stan idealny, a stanem obecnym, przy czym różnice te mają wystarczająco duże znaczenie, aby zmotywować konsumenta do podjęcia działań. Jednocześnie potrzeby mogą mieć charakter fizjologiczny lub psychologiczny, a motywacja będąca siłą napędową działania wywołanego chęcią redukcji dyskomfortu wynikającego z niezaspokojenia potrzeb może być uświadomiona lub nieuświadomiona. Kolejny czynnik, osobowość to unikatowy niepowtarzalny portret psychologiczny danej osoby, który w ogromnym stopniu wpływa na to, w jaki sposób osoba reaguje na swoje otoczenie [Solomon 2006, s. 206]. Postawę można z kolei zdefiniować jako względnie stałą i spójną ocenę określającą stosunek człowieka do określonego obiektu, przedmiotu lub idei [Sowa 2010, s. 141].

Kolejny czynnik wewnętrzny - styl życia określa wzory konsumpcji uzależnione od preferowanych przez klasę społeczną lub grupę konsumentów form spędzania czasu i wydawania pieniędzy. W znaczeniu ekonomicznym styl życia dotyczy sposobów wydawania pieniędzy oraz rodzaju nabywanych dóbr i usług [Duliniec 1986, s. 303].

Wśród czynników zewnętrznych szczególnie ważną rolę odgrywają grupy odniesienia. Są to „takie zbiorowości, do których jednostka należy lub chce należeć, do których odnosi ona swoje postępowanie oraz których systemy wartości i zachowań są podstawą kształtowania jej własnych działań” [Bywalec 2007, s. 58]. Wpływ grup odniesienia może mieć zarówno bezpośredni, jak i pośredni charakter. To właśnie dzięki tym grupom jednostka uczy się zachowań, uczy się jak rozwiązywać problemy związane z konsumpcja, nabiera także charakterystycznych dla danej grupy zwyczajów konsumenckich. Chcąc podkreślić swoją przynależność do konkretnej grupy odniesienia lub podkreślić swój status w tej grupie, konsument może wybrać wiążący się z nią produkt albo markę. Naj- 


\section{6}

bliższą grupą odniesienia jest rodzina, która, zwłaszcza w przypadku młodszych konsumentów, ma najbardziej znaczący wpływ na zachowania spośród wszystkich czynników zewnętrznych. Wynika on z faktu utrzymywania przez konsumenta bliskich relacji z członkami rodziny, co sprzyja wymianie informacji na temat produktów, wspólnemu podejmowaniu decyzji i uczeniu się zachowań konsumenckich. Rodzice stanowią wzór zachowań dla swoich dzieci, a młodzi ludzie naśladują $\mathrm{w}$ zachowaniach swoich rodziców. Z kolei status społeczny i klasa społeczna wynikają z podziału społeczeństwa na klasy będące konsekwencją jego zróżnicowania pod względem statusu, wykształcenia, bogactwa oraz uznawanych wartości [Garbarski (red.) 2011, s. 93]. Członkowie tej samej klasy uznają podobne wartości, mają podobne zainteresowania, podobnie się też zachowują. Czynnikiem decydującym o przynależności do klasy są nie tylko dochody, ale także zawód, wykształcenie, miejsce zamieszkania i styl życia. Kolejne determinanty zewnętrzne, kultura i subkultura bezpośrednio określają normy i zachowania konsumpcyjne społeczeństwa. Shiffman i inni wyjaśniaja, że kultura wyznacza wartości, zwyczaje i tradycje, a członkom społeczeństwa pozwala kontrolować, czy ich zachowania są zgodne wyznaczonymi normami społecznymi [Schiffman i in. 2013, s. 393].

Należy podkreślić, że zachowania konsumentów kształtowane są przez cały zespół czynników, które poza tym, że oddziałują na postępowanie konsumentów, to wpływają także na siebie wzajemnie, modyfikując ostateczne decyzje i powodując, że przewidywanie zachowań nabywców odbywa się w warunkach wysokiej niepewności. U nastolatków procesy zachodzące w czasie wzrastania są bardzo dynamiczne. Równocześnie ze zmianami społecznymi, rozwojem lub zmianą środowiska na zainteresowania i potrzeby tej grupy wpływa bowiem zmienność nastrojów, rozwój moralny, intelektualny, a także intensywne uczenie się i przyswajanie wiedzy.

Wydaje się, że zmiany zachodzące na rynku, takie jak: globalizacja, serwicyzacja, dematerializacja i wirtualizacja, domocentryzm i prywatyzacja konsumpcji, ekokonsumpcja, prosumpcja, konwestycja, homogenizacja i heterogenizacja [procesy te opisano w: Bywalec 2007; Bywalec 2009; Mruk 2009; Sowa 2010; Bywalec 2010; Mróz 2013], dbałość o zdrowie, a także dbałość o dobrą kondycję i wygodę [Olejniczuk-Merta 2015, s. 10] oraz pojawiające się wciąż nowe trendy powoduja, że zachowania młodych konsumentów zaczynają nabierać cech uniwersalnych, charakterystycznych dla rynku globalnego. Porównania zachowań w skali globalnej nie są jednak obecnie możliwe. Prowadzone przez Eurostat badania umożliwiają natomiast dokonanie porównań wybranych zachowań młodzieży w wieku 16-19 lat. 


\section{Charakterystyka zachowań młodych Europejczyków w zakresie wykorzystania Internetu}

W 2014 roku było 7633 tys. młodych Polaków w wieku 15-29 lat, w tym 2081,3 tys. w wieku 15-19 lat [Rocznik demograficzny 2015]. Udział młodych osób (15-29 lat) w populacji naszego kraju spadł w ciągu ostatnich 9 lat z 24,4\% w 2006 roku do 20,2\% w 2014 roku. Analogiczny spadek obserwuje się w większości krajów Unii Europejskiej, przy czym największą jego dynamikę odnotowano w Irlandii. Odwrotną tendencję, tj. wzrost odsetka osób młodych, można zauważyć jedynie w Danii, Luksemurgu, Szwecji, Holandii i Wielkiej Brytanii. Warto przy tym zauważyć, że młodzi konsumenci mają obecnie najmniejszy udział w społeczeństwach Cypru, Słowacji i Polski (tab. 1).

Tabela 1

Udział osób w wieku 15-29 lat w populacji w wybranych krajach Unii Europejskiej [\%]

\begin{tabular}{|l|c|c|c|}
\hline \multirow{2}{*}{ Kraje } & \multicolumn{3}{|c|}{ Odsetek młodzieży w wieku 15-29 lat w społeczeństwie } \\
\cline { 2 - 4 } & 2006 & 2010 & 2014 \\
\hline UE (28) & 19,5 & 18,7 & 17,7 \\
\hline Włochy & 16,6 & 15,7 & 15,3 \\
\hline Hiszpania & 20,4 & 17,9 & 15,6 \\
\hline Polska & 24,4 & 22,6 & 20,2 \\
\hline Cypr & 23,5 & 24,6 & 22,7 \\
\hline Dania & 17,3 & 17,9 & 18,8 \\
\hline Irlandia & 23,8 & 22,3 & 18,2 \\
\hline
\end{tabular}

Źródło: Ratio of young people in the total population on 1 January by sex and age, http:// appsso.eurostat.ec.europa.eu/nui/show.do (data dostępu: listopad 2015).

Pochodzące z Eurostatu dane pozwalają też ocenić aktywność młodych konsumentów mierzoną częstością ich kontaktów ze znajomymi, przy czym chodzi tu zarówno o kontakty bezpośrednie (spotkania), jak i pośrednie (np. przez Internet). Ponad połowa $\mathrm{z}$ osób w wieku 16-19 lat $(53,6 \%)$ co najmniej raz w tygodniu kontaktuje się z bliskimi, a tylko nieznacznie mniejsza grupa $(51,7 \%)$ ze znajomymi się spotyka. Na tym tle młodzi Polacy wypadają trochę gorzej. Zaledwie $45,3 \% \mathrm{z}$ nich co najmniej raz w tygodniu kontaktuje się ze znajomymi, a 37,4\% z taką samą częstotliwością się z nimi spotyka.

Aż 5,7\% młodych Europejczyków stwierdza, że nigdy nie kontaktuje się ze znajomymi i 1,7\%, że nigdy się z nimi nie spotyka. Wśród Polaków ten odsetek jest niższy: wynosi odpowiednio 3,3\% i 0,9\%. Tak więc Polacy spotykają się ze znajomymi rzadziej niż ich europejscy rówieśnicy, ale życie towarzyskie podejmuje więcej młodych Polaków (tab. 2) 
Dość powszechnie (a nawet częściej niż przeciętnie w UE) polska młodzież w wieku 16-19 lat korzysta z Internetu. W 2011 roku 89\% młodych Polaków codziennie korzystało z Internetu, a w Unii ten odsetek wynosił zaledwie $82 \%$. W roku 2014 proporcje te zmieniły się tylko nieznacznie - z Internetu korzystało 92\% młodych Polaków i 90\% młodzieży unijnej [Individuals - frequency of internet use, http://appsso.eurostat.ec.europa.eu/nui/submitViewTableAction. do]. Uwagę zwraca przy tym fakt, że młodzi Polacy używają Internetu w bardziej zróżnicowany sposób niż młodzież europejska. Aż 91\% młodych Polaków i tylko 77\% ich europejskich rówieśników korzysta z czatów oraz uczestniczy w dyskusjach na forach internetowych. Nieco ponad połowa Polaków (51\%) i Europejczyków (53\%) korzysta przez Internet z połączeń telefonicznych, 39\% Polaków i 32\% młodych Europejczyków dzieli się i wymienia filmami, muzyką i innymi zasobami, około $18 \%$ młodzieży tworzy strony internetowe, a prawie wszyscy (98\% Polaków i 96\% młodzieży unijnej) poszukuje informacji za pomocą wyszukiwarek [Individuals - frequency of internet use, http://appsso.eurostat.ec.europa.eu/nui/submitViewTableAction.do].

\section{Tabela 2}

Częstotliwość spotkań i kontaktów z bliskimi oraz ze znajomymi 16-19-latków z Polski i Unii Europejskiej [\% odpowiedzi]

\begin{tabular}{|l|c|c|c|c|c|c|}
\hline $\begin{array}{l}\text { Wyszcze- } \\
\text { gólnienie }\end{array}$ & Codziennie & Co tydzień & $\begin{array}{c}\text { Raz w mie- } \\
\text { siącu }\end{array}$ & $\begin{array}{c}\text { Kilka razy } \\
\text { w miesiącu }\end{array}$ & $\begin{array}{c}\text { Przynajm- } \\
\text { niej raz } \\
\text { w roku }\end{array}$ & Nigdy \\
\hline \multicolumn{7}{|c|}{ Częstotliwość kontaktów ze znajomymi } \\
\hline Europa & 19,2 & 34,4 & 12,4 & 19,7 & 8,3 & 5,7 \\
\hline Polska & 15,9 & 29,4 & 15,2 & 23,2 & 12,7 & 3,3 \\
\hline \multicolumn{7}{|c|}{ Częstotliwość spotkań ze znajomymi } \\
\hline Europa & 18,8 & 32,9 & 13,7 & 20,2 & 12,6 & 1,7 \\
\hline Polska & 8,9 & 28,5 & 16,8 & 26,8 & 17,7 & 0,9 \\
\hline
\end{tabular}

Źródło: Frequency of getting together with relatives or friends by sex and age, http://appsso. eurostat.ec.europa.eu/nui/show.do?dataset=yth_part_010\&lang=en; Frequency of contacts with relatives or friends by sex and age, http://appsso.eurostat.ec.europa.eu/nui/show.do?dataset=yth_part_020\&lang=en (data dostępu: luty 2015).

Podsumowując porównanie wybranych zachowań młodzieży polskiej na tle jej europejskich rówieśników należy zwrócić uwagę na istnienie zróżnicowania w poziomie uczestnictwa w życiu społecznym oraz korzystania z nowoczesnych technologii. Polacy rzadsze kontakty ze znajomymi rekompensują sobie większą aktywnością w korzystaniu z Internetu i wykorzystywaniu jego funkcji i możliwości. Wydaje się więc, że wśród polskiej młodzieży silniej występuje zjawisko wirtualizacji zachowań. 


\section{Metodyka badań}

Badania pierwotne przeprowadzone były metodą ankiety audytoryjnej kolejno w 2004, 2006 i 2014 roku. Uczestniczyli w nich uczniowie klas 1 i 3 szkół gimnazjalnych i ponadgimnazjalnych (liceów oraz szkół zawodowych) z województw śląskiego, małopolskiego (tylko w roku 2004) i łódzkiego (tylko w roku 2006). Badani byli w wieku od 14 do 19 lat. Strukturę respondentów przedstawiono w tabeli 3.

Tabela 3

Struktura próby z lat 2004, 2006 i 2014 według płci i rodzaju szkoły

\begin{tabular}{|l|c|c|c|c|c|}
\hline \multirow{2}{*}{ Rodzaj szkoły } & \multicolumn{4}{|c|}{ liczba badanych } & \multicolumn{2}{|c|}{ Odsetek badanych } & \multirow{2}{*}{ Ogółem } \\
\cline { 2 - 5 } & Dziewczyna & Chłopak & $\begin{array}{c}\text { Dziewczy- } \\
\text { na }\end{array}$ & Chłopak & \\
\hline & \multicolumn{5}{|c|}{2004 rok } \\
\hline Gimnazjum & 268 & 245 & $52 \%$ & $48 \%$ & 513 \\
\hline Ponadgimnazjalna & 498 & 327 & $60 \%$ & $40 \%$ & 825 \\
\hline Razem & 766 & 572 & $57 \%$ & $43 \%$ & 1338 \\
\hline & \multicolumn{5}{|l|}{2006} \\
\hline Gimnazjum & 359 & 322 & $53 \%$ & $47 \%$ & 681 \\
\hline Ponadgimnazjalna & 525 & 643 & $45 \%$ & $55 \%$ & 1168 \\
\hline Razem & 884 & 965 & $48 \%$ & $52 \%$ & 1849 \\
\hline & \multicolumn{5}{|l|}{2014} \\
\hline Gimnazjum & 129 & 158 & $45 \%$ & $55 \%$ & 287 \\
\hline Ponadgimnazjalna & 393 & 253 & $61 \%$ & $39 \%$ & 646 \\
\hline Razem & 522 & 411 & $56 \%$ & $44 \%$ & 933 \\
\hline
\end{tabular}

Źródło: Opracowanie własne na podstawie badań bezpośrednich.

Przedmiotem badań była częstotliwość wykonywania następujących czynności: gra na komputerze, rozmowy i czatowanie przez Internet, spotkania ze znajomymi na podwórku, spotkania w pubach, kawiarniach, czytanie ksiazżek, czytanie prasy, podejmowanie pracy zarobkowej, korzystanie z dodatkowych lekcji i korepetycji, uprawianie sportu w klubach oraz indywidualne uprawianie sportu i pomoc w domu. Respondenci określali tę częstotliwość, mając do dyspozycji odpowiedzi: ,nigdy”, ,raz w roku lub rzadziej”, ,kilka razy w roku”, ,kilka razy w miesiącu”, ,kilka razy w tygodniu”, „,codziennie”. Chcąc określić średnią częstotliwość poszczególnych czynności do dalszych analiz przyjęto następujące wartości obrazujące liczbę dni w ciągu roku, w których dokonywano czynności: nigdy -0 , raz w roku lub rzadziej - 1, kilka razy w roku -4 , kilka razy w miesiącu -36 , kilka razy w tygodniu -156 oraz codziennie -365 .

Następnie zastosowano test nieparametryczny Kruskala-Wallisa w celu weryfikacji następujących hipotez: 
H1 Zachowania młodych konsumentów są determinowane przez ich płeć.

H2 Wiek jest czynnikiem kształtującym zachowania młodych konsumentów.

H3 Poziom wykształcenia rodziców wpływa na zachowanie nastoletnich konsumentów.

H4 Miejsce zamieszkania (wieś lub miasto) determinuje zachowania e-młodzieży.

H5 Zachowania młodzieży uzależnione są od wysokości środków pieniężnych, jakie ma do dyspozycji.

Omawiając zróżnicowanie zachowań pod wpływem wybranych czynników, w tabelach 4 i 6 przedstawiono średnie częstotliwości dla respondentów wyodrębnionych na podstawie badanych cech.

\section{Zachowania młodych polskich konsumentów}

Biorąc pod uwagę deklaracje respondentów dotyczące podejmowania różnych czynności można zauważyć, że aktywność młodych ludzi skupia się przede wszystkim na rozrywce i utrzymywaniu kontaktów towarzyskich. Coraz częstej korzystają oni z komputerów - chociaż w kolejnych etapach badań odsetek osób grających na komputerach jest mniej więcej taki sam, to wzrasta odsetek tych, którzy grają codziennie (w 2004 roku było to $26 \%$, w $2014-33,7 \%$ ) - tab. 4.

$\mathrm{W}$ badanych latach dynamicznie rosło wykorzystywanie komputerów do komunikowania się. O ile w roku $2004 \mathrm{z}$ tej możliwości nigdy nie korzystało aż $21,3 \%$ badanych, to w roku 2014 podobną deklarację złożyło zaledwie 2,6\% respondentów. Osoby komunikujące się przez Internet co najmniej kilka razy w tygodniu stanowiły w kolejnych próbach odpowiednio: 52,9\% w roku 2004, 63,9\% w roku 2006 i 89,6\% w 2014 roku. Wzrastał także odsetek młodzieży spotykającej się ze znajomymi w kawiarniach i pubach (odpowiednio malał odsetek osób deklarujących, że nigdy z takich miejsc nie korzysta, a rósł odsetek tych, którzy spotykają się $\mathrm{w}$ kawiarniach i pubach co najmniej kilka razy $\mathrm{w}$ tygodniu - z 21,1\% w 2004 roku do 28\% w 2014 roku. Spadł natomiast odsetek młodzieży spotykającej się w barach i pubach codziennie (z 5,5\% w 2006 roku do 3,7\% w 2014 roku). Najwięcej młodzieży korzystało z tych punktów gastronomicznych kilka razy w miesiącu (w 2004 roku 37,9\%, a w 2014 - 45,3\%) - tabele 4 i 5.

Jednocześnie zaobserwowano spadek zainteresowania spotkaniami z rówieśnikami na podwórku, osiedlu, w parku itp. W 2004 roku 78,2\% młodzieży spotykało się $\mathrm{w}$ tych miejscach $\mathrm{z}$ rówieśnikami co najmniej kilka razy w tygodniu, przy czym ponad 1/3 badanych robiła to codziennie. W 2014 roku już tylko co piąty badany deklarował codzienne spotkania z kolegami, a prawie połowa respondentów gromadziła się poza domem kilka razy w tygodniu. Wyniki przeprowadzonych badań wskazują także, że młodzież coraz rzadziej pomaga w domu. 
Tabela 4

Częstotliwość podejmowania wybranych czynności przez respondentów [\%] oraz średnia liczba dni w roku, w których realizowano czynność według cech respondentów w 2004 roku

\begin{tabular}{|c|c|c|c|c|c|c|c|c|c|c|c|c|c|}
\hline \multirow{2}{*}{ 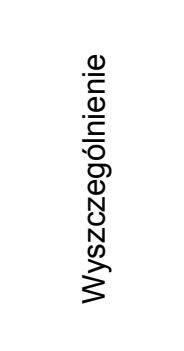 } & \multicolumn{6}{|c|}{$\begin{array}{c}\text { Odsetek respondentów } \\
\text { deklarujących realizację czynności } \\
\text { z następującą częstotliwością } \\
{[\%]}\end{array}$} & \multicolumn{7}{|c|}{$\begin{array}{l}\text { Średnia liczba dni w roku, w których } \\
\text { realizowano czynność }\end{array}$} \\
\hline & के & 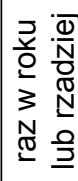 & 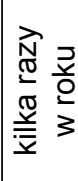 & 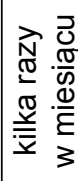 & 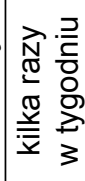 & 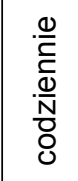 & 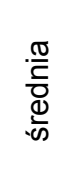 & $\begin{array}{l}\frac{0}{10} \\
\frac{0}{E} \\
\frac{0}{E}\end{array}$ & $\stackrel{\infty}{\infty}$ & 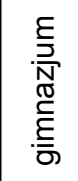 & 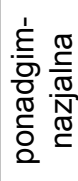 & 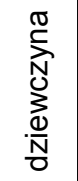 & $\begin{array}{l}\frac{y}{\pi} \\
\frac{0}{2} \\
\frac{0}{0}\end{array}$ \\
\hline $\begin{array}{l}\text { Pomoc } \\
\text { w domu }\end{array}$ & 2,6 & 0,9 & 1,8 & 10,0 & 34,7 & 50,0 & 240 & $229 *$ & 278 & 249 & 235 & 264 & 211 \\
\hline $\begin{array}{l}\text { Spotkania } \\
\text { ze znajo- } \\
\text { mymi na } \\
\text { podwórku }\end{array}$ & 4,4 & 1,1 & 3,0 & 13,3 & 41,9 & 36,3 & 203 & 201 & 209 & 219 & 192 & 191 & 217 \\
\hline $\begin{array}{l}\text { Rozmowy } \\
\text { przez Inter- } \\
\text { net }\end{array}$ & 21,3 & 3,0 & 8,5 & 14,3 & 18,2 & 34,7 & 160 & 182 & 89 & 125 & 182 & 152 & 173 \\
\hline $\begin{array}{l}\text { Gra na } \\
\text { komputerze }\end{array}$ & 13,9 & 2,5 & 8,8 & 19,7 & 29,1 & 26,0 & 148 & 147 & 149 & 179 & 128 & 108 & 202 \\
\hline $\begin{array}{l}\text { Czytanie } \\
\text { prasy }\end{array}$ & 3,8 & 1,7 & 5,3 & 31,1 & 38,9 & 19,2 & 142 & 142 & 144 & 148 & 138 & 142 & 143 \\
\hline $\begin{array}{l}\text { Indywidual- } \\
\text { ne uprawia- } \\
\text { nie sportu }\end{array}$ & 24,2 & 2,9 & 8,9 & 20,7 & 26,4 & 16,9 & 111 & 108 & 121 & 130 & 99 & 78 & 155 \\
\hline $\begin{array}{l}\text { Czytanie } \\
\text { książek }\end{array}$ & 13,8 & 7,7 & 25,3 & 24,2 & 17,0 & 12,0 & 80 & 83 & 71 & 91 & 74 & 93 & 65 \\
\hline $\begin{array}{l}\text { Uprawianie } \\
\text { sportu } \\
\text { w klubach }\end{array}$ & 40,6 & 3,5 & 6,5 & 14,2 & 26,3 & 8,9 & 79 & 79 & 80 & 96 & 69 & 64 & 97 \\
\hline $\begin{array}{l}\text { Spotkania } \\
\text { w pubach, } \\
\text { kawiarniach }\end{array}$ & 17,0 & 7,5 & 16,5 & 37,9 & 17,4 & 3,7 & 55 & 56 & 52 & 50 & 58 & 53 & 56 \\
\hline $\begin{array}{l}\text { Nauka języ- } \\
\text { ków, kore- } \\
\text { petycje }\end{array}$ & 48,2 & 4,3 & 5,2 & 13,8 & 25,8 & 2,7 & 55 & 60 & 40 & 57 & 54 & 61 & 47 \\
\hline $\begin{array}{l}\text { Praca za- } \\
\text { robkowa }\end{array}$ & 58,0 & 13,7 & 12,4 & 8,1 & 5,7 & 2,1 & 20 & 18 & 27 & 24 & 18 & 13 & 30 \\
\hline
\end{tabular}

*Boldem zaznaczono te dane, dla których istotność asymptotyczna w teście Kruskala-Wallisa była mniejsza niż 0,05 , co pozwoliło na odrzucenie hipotez mówiących o braku różnic między grupami wyodrębnionymi na podstawie badanych cech.

Żródło: Opracowanie własne na podstawie badań bezpośrednich. 
Tabela 5

Częstotliwość podejmowania wybranych czynności przez respondentów w 2006 i 2014 roku [\%]

\begin{tabular}{|c|c|c|c|c|c|c|c|c|c|c|c|c|}
\hline \multirow{3}{*}{ 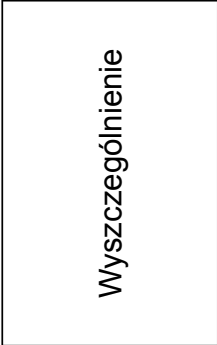 } & \multicolumn{12}{|c|}{$\begin{array}{l}\text { Częstotliwość realizowania wybranych aktywności w latach } 2006 \text { i } 2013 \\
\text { w procentach wskazań }\end{array}$} \\
\hline & के & 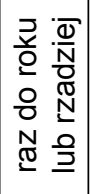 & 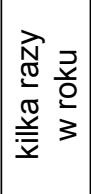 & 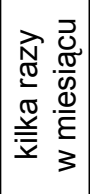 & 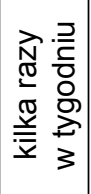 & 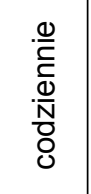 & 离 & 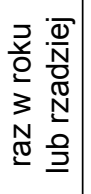 & 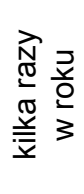 & 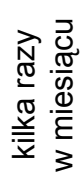 & 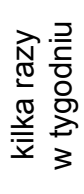 & $\begin{array}{l}. \frac{0}{E} \\
\frac{0}{0} \\
\frac{\mathscr{D}}{N} \\
\frac{0}{0}\end{array}$ \\
\hline & \multicolumn{6}{|c|}{2006} & \multicolumn{6}{|c|}{2013} \\
\hline $\begin{array}{l}\text { Spotkania na } \\
\text { podwórku }\end{array}$ & 3,1 & 1,5 & 3,0 & 13,0 & 38,7 & 40,7 & 3,2 & 2,2 & 5,1 & 19,3 & 49,1 & 21,1 \\
\hline $\begin{array}{l}\text { Pomoc } \\
\text { w domu }\end{array}$ & 3,1 & 1,0 & 3,6 & 14,5 & 38,3 & 39,4 & 4,4 & 1,8 & 2,8 & 17,2 & 39,6 & 34,1 \\
\hline $\begin{array}{l}\text { Czytanie } \\
\text { prasy }\end{array}$ & 6,1 & 2,9 & 7,9 & 29,6 & 36,5 & 17,1 & 10,9 & 7 & 13,8 & 33,5 & 24,5 & 10,3 \\
\hline $\begin{array}{l}\text { Gra na kom- } \\
\text { puterze }\end{array}$ & 11,6 & 4,5 & 7,5 & 17,1 & 28,7 & 30,6 & 13,5 & 6,6 & 7,5 & 11,1 & 27,6 & 33,7 \\
\hline $\begin{array}{l}\text { Spotkania } \\
\text { w pubach, } \\
\text { kawiarniach }\end{array}$ & 15,6 & 7,1 & 16,1 & 34,7 & 21,3 & 5,2 & 7,5 & 6,3 & 12,9 & 45,3 & 24,3 & 3,7 \\
\hline $\begin{array}{l}\text { Czytanie } \\
\text { książek }\end{array}$ & 16,0 & 11,9 & 26,0 & 20,7 & 14,9 & 10,4 & 10,6 & 10,4 & 23,1 & 25,6 & 17,3 & 13,1 \\
\hline $\begin{array}{l}\text { Rozmowy } \\
\text { przez Internet }\end{array}$ & 16,5 & 3,3 & 5,2 & 11,0 & 20,7 & 43,2 & 2,6 & 1,1 & 1,6 & 5,2 & 21 & 68,6 \\
\hline $\begin{array}{l}\text { Indywidualne } \\
\text { uprawianie } \\
\text { sportu }\end{array}$ & 22,0 & 5,2 & 9,3 & 19,0 & 23,9 & 20,6 & 26,5 & 4,2 & 9,2 & 18,6 & 24,8 & 16,5 \\
\hline $\begin{array}{l}\text { Zajęcia } \\
\text { sportowe } \\
\text { w klubach }\end{array}$ & 37,1 & 6,6 & 7,1 & 12,2 & 26,5 & 10,4 & 34,9 & 6,1 & 7,9 & 13,1 & 30,1 & 8 \\
\hline $\begin{array}{l}\text { Praca } \\
\text { zarobkowa }\end{array}$ & 38,9 & 12,6 & 15,2 & 14,7 & 13,0 & 5,6 & 46,3 & 14,4 & 17,4 & 12,1 & 7 & 2,8 \\
\hline $\begin{array}{l}\text { Dodatkowe } \\
\text { lekcje }\end{array}$ & 46,1 & 8,1 & 7,5 & 15,2 & 21,2 & 1,9 & 29,6 & 5,6 & 8,2 & 17,2 & 34,9 & 4,5 \\
\hline
\end{tabular}

Źródło: Opracowanie własne na podstawie badań bezpośrednich.

W 2004 roku prace na rzecz rodziny wykonywało 98,4\% młodzieży, a połowa robiła to codziennie.

W 2014 roku już tylko co trzeci nastolatek pomagał w domu każdego dnia. Być może zmianę tę uzasadnia fakt, że coraz więcej młodych osób pracuje zarobkowo poza domem. W 2004 roku nie pracowało 58\% młodych osób, w 2014 
już tylko 46,3\%. Najniższy odsetek niepracujących poza domem odnotowano w 2006 roku - 38,9\%. Ponadto należy stwierdzić, że wzrasta częstotliwość podejmowania przez młodych pracy zarobkowej. W 2004 roku najwięcej badanych $(13,7 \%)$ podejmowało płatne zajęcia raz w roku lub rzadziej, natomiast w 2006 i 2014 roku najczęściej deklarowano pracę ,kilka razy w roku” (odpowiednio 15,2 i $17,4 \%$ ). W podobnie jednoznaczny sposób nie zmieniła się w badanym okresie częstotliwość uprawiania sportu, czytania książek oraz korzystania z korepetycji i dodatkowych lekcji.

Przeprowadzony test Kruskala-Wallisa pozwolił określić jakie czynniki kształtują zachowania młodzieży. Zgodnie z nim czynnikiem mającym wpływ na większość badanych zachowań jest wiek respondentów ${ }^{1}$ (tab. 6). Wraz $\mathrm{z}$ wiekiem i przechodzeniem na wyższe poziomy edukacji spada zainteresowanie grami komputerowymi, a rośnie wykorzystanie komputera do komunikacji $\mathrm{z}$ innymi. Starsi badani częściej bywali w kawiarniach i pubach (najstarsi badani bywali tam około $78 \mathrm{dni}$ w ciagu roku, a najmłodsi nieco ponad $65 \mathrm{dni}$ ). $\mathrm{Z}$ wiekiem badanych było też związane uprawianie sportu (zarówno w klubach, jak i indywidualnie). W gimnazjum częstotliwość takich zachowań jest większa, znacząco maleje natomiast w szkole ponadgimnazjalnej, zwłaszcza w klasie III (maturalnej). Podobną sytuację odnotowano w przypadku spotkań ze znajomymi na podwórku - najrzadziej spotykają się uczniowie ostatnich klas szkół ponadgimnazjalnych. Z kolei odwrotna zależność dotyczyła dodatkowych lekcji i korepetycji - uczniowie klas maturalnych korzystają z takich zajęć znacznie częściej niż przeciętny badany.

Płeć jest czynnikiem różnicującym większość zachowań młodzieży poza rozmowami przez komputer, spotkaniami na podwórku (w 2006), spotkaniami w pubach (w 2013) i czytaniem prasy (w 2013). Chłopcy prawie dwukrotnie częściej niż dziewczęta grają na komputerze (w 2006 roku odpowiednio 205 dni i 117 dni, a w 2014 roku 219 dni i 132 dni w ciągu roku), częściej spotykają się ze znajomymi na podwórku (średnio 217 dni w 2004 i 231 w 2006 roku, a dziewczęta nieco ponad 190 dni), o połowę częściej niż dziewczęta uprawiają też sport w klubach (około 100 razy w ciągu roku, a dziewczęta około 65 razy) oraz indywidualnie. Ponadto stwierdzono, że dziewczęta częściej pomagaja w domu, a chłopcy częściej pracują zarobkowo.

Miejsce zamieszkania jest czynnikiem determinującym aktywność młodzieży w dziedzinie korzystania z komunikacji za pomocą Internetu i korzystania $\mathrm{z}$ zajęć sportowych w klubach. Pomoc w domu, podejmowanie pracy zarobkowej oraz indywidualne uprawianie sportu determinowane było przez miejsce zamieszkania tylko w niektórych latach.

\footnotetext{
${ }^{1}$ Dla ułatwienia rozważań zamiast prezentować dane w grupach wiekowych, respondentów podzielono na grupy według poziomu nauczania i w taki sposób prezentowane będą dane
} 
Tabela 6

Średnia liczba dni w roku, w których realizowano czynność według cech respondentów w 2006 i 2014 roku

\begin{tabular}{|c|c|c|c|c|c|c|c|c|c|}
\hline \multirow{2}{*}{ 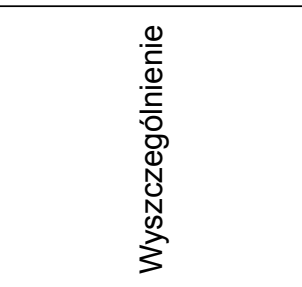 } & \multicolumn{9}{|c|}{$\begin{array}{l}\text { Średnia liczba dni w roku, w których realizowano czynność wedłuc } \\
\text { cech respondentów w latach }\end{array}$} \\
\hline & $\begin{array}{l}\frac{\pi}{\frac{\pi}{\tau}} \\
\frac{d}{0} \\
\frac{.0}{\omega}\end{array}$ & 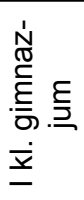 & 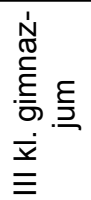 & 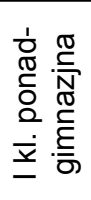 & 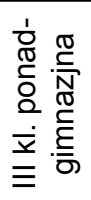 & $\begin{array}{l}\frac{0}{\mathscr{N}} \\
\stackrel{0}{\frac{0}{E}}\end{array}$ & $\frac{\infty}{3}$ & 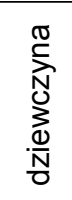 & 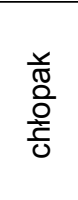 \\
\hline & \multicolumn{9}{|c|}{2006} \\
\hline $\begin{array}{l}\text { Spotkania na } \\
\text { podwórku }\end{array}$ & $213,6^{*}$ & 242 & 206 & 226 & 204 & 214 & 213 & 195 & 231 \\
\hline Pomoc w domu & 209,1 & 186 & 215 & 206 & 195 & 204 & 225 & 242 & 179 \\
\hline $\begin{array}{l}\text { Rozmowy przez } \\
\text { Internet }\end{array}$ & 194,3 & 178 & 205 & 209 & 205 & 212 & 136 & 190 & 198 \\
\hline Gra na komputerze & 162,8 & 156 & 173 & 164 & 122 & 164 & 157 & 117 & 205 \\
\hline Czytanie prasy & 130,2 & 109 & 133 & 123 & 117 & 129 & 134 & 137 & 124 \\
\hline $\begin{array}{l}\text { Indywidualne } \\
\text { uprawianie sportu }\end{array}$ & 119,7 & 103 & 124 & 122 & 99 & 119 & 123 & 81 & 155 \\
\hline $\begin{array}{l}\text { Zajęcia sportowe } \\
\text { w klubach }\end{array}$ & 84,2 & 73 & 103 & 78 & 60 & 88 & 72 & 65 & 101 \\
\hline Czytanie książek & 70,0 & 20 & 79 & 56 & 62 & 74 & 57 & 92 & 50 \\
\hline $\begin{array}{l}\text { Spotkania w pubach, } \\
\text { kawiarniach }\end{array}$ & 65,6 & 67 & 61 & 75 & 78 & 63 & 74 & 61 & 70 \\
\hline Praca zarobkowa & 46,6 & 45 & 23 & 54 & 66 & 45 & 52 & 29 & 63 \\
\hline \multirow[t]{2}{*}{ Dodatkowe lekcje } & 45,8 & 30 & 53 & 35 & 49 & 51 & 28 & 54 & 38 \\
\hline & \multicolumn{9}{|c|}{2014} \\
\hline $\begin{array}{l}\text { Rozmowy przez } \\
\text { Internet }\end{array}$ & 285,0 & 245 & 262 & 313 & 279 & 293 & 247 & 302 & 264 \\
\hline Pomoc w domu & 192,4 & 171 & 204 & 186 & 205 & 194 & 185 & 207 & 174 \\
\hline Gra na komputerze & 170,5 & 230 & 213 & 155 & 139 & 158 & 228 & 132 & 219 \\
\hline $\begin{array}{l}\text { Spotkania ze na } \\
\text { podwórku }\end{array}$ & 160,8 & 160 & 170 & 179 & 131 & 161 & 162 & 156 & 167 \\
\hline $\begin{array}{l}\text { Indywidualne } \\
\text { uprawianie sportu }\end{array}$ & 106,1 & 109 & 110 & 111 & 95 & 100 & 135 & 97 & 117 \\
\hline Czytanie prasy & 88,6 & 86 & 92 & 87 & 90 & 87 & 97 & 89 & 88 \\
\hline Czytanie książek & 84,9 & 84 & 75 & 85 & 92 & 87 & 74 & 99 & 67 \\
\hline $\begin{array}{l}\text { Zajęcia sportowe } \\
\text { w klubach }\end{array}$ & 81,2 & 89 & 106 & 81 & 64 & 76 & 103 & 67 & 99 \\
\hline Dodatkowe lekcje & 77,5 & 90 & 76 & 66 & 89 & 76 & 86 & 82 & 71 \\
\hline $\begin{array}{l}\text { Spotkania w pubach, } \\
\text { kawiarniach }\end{array}$ & 68,2 & 52 & 68 & 68 & 77 & 70 & 62 & 69 & 67 \\
\hline Praca zarobkowa & 26,4 & 30 & 22 & 21 & 35 & 24 & 38 & 21 & 33 \\
\hline
\end{tabular}

*Boldem zaznaczono te dane, dla których istotność asymptotyczna w teście Kruskala-Wallisa była mniejsza niż 0,05 , co pozwoliło na odrzucenie hipotez mówiących o braku różnic między grupami wyodrębnionymi na podstawie badanych cech.

Żródło: Opracowanie własne na podstawie badań bezpośrednich. 
Rozmowy przez Internet zdecydowanie częściej prowadzone są przez mieszkańców miast, choć w ostatnich latach mieszkańcy wsi i miast upodabniają się do siebie pod względem częstotliwości korzystania z tego medium. Wynika to w dużej mierze z poprawy infrastruktury na wsi. Mieszkańcy wsi częściej niż ich koledzy mieszkający w miastach: grają na komputerze, pomagają w domu, pracują zarobkowo i uprawiają sport indywidualnie, rzadziej natomiast korzystają $\mathrm{z}$ dodatkowych lekcji i korepetycji.

W trakcie przeprowadzonych badań stwierdzono także, że czynnikiem mającym wpływ na zachowania podejmowane przez dzieci jest wykształcenie rodziców. Wykształcenie ojca wpływało na różnicowanie wszystkich badanych zachowań, natomiast wykształcenie matki nie wpływało jedynie (w 2006 roku) na częstotliwość czytania prasy oraz pomoc $\mathrm{w}$ domu. Zaobserwowano, że wraz ze wzrostem poziomu wykształcenia rodziców rośnie częstotliwość wykonywania przez potomków większości badanych czynności: czytania książek i prasy, korzystania z korepetycji, uprawiania sportu w klubach, korzystania z komputera $\mathrm{w}$ celu komunikowania się $\mathrm{z}$ innymi oraz po to, aby grać. Największe różnice obserwuje się w odniesieniu do spotkań w pubach i kawiarniach - dzieci rodziców z wyższym wykształceniem bywają tam dwukrotnie częściej niż dzieci osób z wykształceniem podstawowym lub zawodowym. Wraz z poziomem wykształcenia rodziców spada częstotliwość pomocy świadczonej przez dzieci na rzecz domu. Wraz ze wzrostem poziomu wykształcenia rodziców rośnie częstotliwość spotkań z rówieśnikami poza domem, ale dotyczy to tylko dzieci, których rodzice mają wykształcenie co najwyżej średnie (dzieci rodziców z wykształceniem wyższym rzadziej spotykają się z kolegami poza domem). Te związki mają charakter uniwersalny - obserwuje się je we wszystkich badanych latach. Wyjątkiem jest granie na komputerze - w 2014 roku wraz ze wzrostem poziomu wykształcenie rodziców, częstotliwość grania na komputerach spadała.

Kolejnym analizowanym czynnikiem była wysokość kieszonkowego, jaką dysponuje młodzież. Stwierdzono, że cecha ta determinuje korzystanie z komunikacji przez Internet, częstotliwość spotkań ze znajomymi na podwórku oraz w pubach, czytanie książek, korzystanie z korepetycji oraz pomoc na rzecz gospodarstwa domowego. Młode osoby dysponujące wyższymi kwotami częściej korzystają z komunikatorów i spotykają się ze znajomymi w pubach i kawiarniach niż ich ubożsi rówieśnicy. Rzadziej natomiast czytają książki i rzadziej pomagają rodzicom. Z korepetycji i lekcji dodatkowych najczęściej korzystają konsumenci, których miesięczne kieszonkowe mieści się w wartościach środkowych (od 25 do 200 złotych).

Zachowania młodych konsumentów ewoluują, czego przejawem jest między innymi zmiana częstotliwości podejmowania różnych aktywności, będąca rezultatem przemian w stylach życia i sposobach zagospodarowania czasu wolnego. 
Efektem tego jest zmiana hierarchii podejmowanych czynności. W 2004 roku najczęstszą aktywnością podejmowaną przez młodzież była pomoc $\mathrm{w}$ domu (240 razy w roku), spotkania ze znajomymi (203 razy), korzystanie z komunikatorów (160 razy), granie na komputerze (147) i czytanie prasy (142). Najrzadziej bywano w pubach i korzystano z korepetycji (po 55 razy) oraz podejmowano pracę zarobkową (20 razy). W 2006 roku pomoc w domu spadła na drugą pozycję - młodzież częściej spotykała się ze znajomymi (213 razy), korzystała także z komunikatorów (194 razy) oraz grała w gry komputerowe (163 razy). Do najrzadziej podejmowanych aktywności, podobnie jak 2 lata wcześniej, należały korepetycje i praca dodatkowa. W 2014 roku najczęściej deklarowaną aktywnością było komunikowanie się przez Internet (285 razy), pomoc w domu oraz granie na komputerze (170 razy). Spotkania ze znajomymi znalazły się na 4. pozycji (160 razy w ciagu roku). Czytanie prasy, które 2004 roku było czynnością równie częstą, jak granie $\mathrm{w}$ gry komputerowe, w 2014 razy miało miejsce prawie o połowę rzadziej.

\section{Podsumowanie i wnioski}

Zebrane dane pozwoliły na weryfikację hipotez szczegółowych. Potwierdzona została hipoteza 1, zgodnie z którą zachowania młodych konsumentów są determinowane przez ich płeć. Płeć wpływa na większość badanych zachowań poza bywaniem w pubach i kawiarniach oraz czytaniem prasy (w 2004 roku) i korzystaniem z komunikatorów (2004 i 2006 rok). Chłopcy częściej grają na komputerze, spotykają się ze znajomi na podwórku, uprawiają sport oraz pracują zarobkowo. Dziewczęta natomiast częściej pomagają w domu, czytają książki i korzystają z korepetycji. Jednocześnie należy zauważyć, że sposób oddziaływania płci w poszczególnych latach był stały.

Potwierdzona zastała także hipoteza 2, dotycząca oddziaływania wieku. We wszystkich badanych latach wiek wpływał na spotkania w pubach i kawiarniach (liczba spotkań rośnie wraz z wiekiem), rozmowy przez Internet oraz udział w zajęciach sportowych (ich częstotliwość rośnie wraz z wiekiem, ale maleje w ostatniej klasie szkoły ponadgimnazjalnej) oraz granie na komputerze (młodsi badani grają częściej niż starsi). W odniesieniu do pozostałych zachowań znaczenie wieku zmieniało się w kolejnych latach.

Częściowo potwierdziły się hipotezy 3, 4 i 5. W kolejnych latach zauważono zmianę kierunku oddziaływania i spadek znaczenia poziomu wykształcenia rodziców w kształtowaniu zachowań dzieci. Kierunek oddziaływania tego czynnika na częstotliwość grania na komputerze odwrócił się w 2014 roku w stosunku do lat 2004 i 2006 - najpierw był stymulanta, obecnie jest destymulantą tych zachowań. 
Miejsce zamieszkania wpływa tylko na niektóre zachowania młodych osób. Nie determinuje takich zachowań jak spotkania na podwórku, w pubach, indywidualne uprawianie sportu, czytanie prasy. Różnice między zachowaniami młodzieży miejskiej i wiejskiej nie są w poszczególnych latach jednakowe. Również wysokość środków pieniężnych, jakie ma do dyspozycji młodzież, wpływa na zachowania w sposób niejednoznaczny. W poszczególnych latach wysokość „,kieszonkowego” odmiennie różnicuje zachowania. Jest to prawdopodobnie związane z pojawianiem się możliwości uzyskiwania stypendium przez dzieci rodziców najuboższych, a także z podejmowaniem pracy przez młodzież zarówno najbiedniejsza, jak i dobrze uposażoną. Przedmiotem dalszych dociekań powinien więc być nie tylko związek między zachowaniami a pieniędzmi do dyspozycji, ale także źródeł ich pozyskiwania i kierunków wydatkowania, a zwłaszcza określenia, czy posiadane pieniądze przeznaczane są na zaspokojenie potrzeb podstawowych czy wyższego rzędu.

Podsumowując wyniki przeprowadzonych badań należy stwierdzić, że zachowania młodzieży są odpowiedzią na pojawiające się trendy rynkowe: wirtualizację, serwicyzację, a także odchodzenie od tradycyjnych mediów. Ponadto można zauważyć zwiększenie zainteresowania sportem, zwłaszcza wśród młodych dziewcząt, co jest zgodne $\mathrm{z}$ dostrzeganym obecnie na rynku trendem dbania o zdrowie i wygląd.

Przeprowadzone analizy oddziaływania poszczególnych czynników na zachowania młodzieży wskazuja, że determinowanie zachowań przez poszczególne czynniki nie jest zjawiskiem stałym i uniwersalnym. Niektóre czynniki (jak na przykład wiek, płeć) mają wpływ na wiele zachowań, a wpływ ten utrzymuje się w poszczególnych latach. Inne zmienne (na przykład miejsce zamieszkania, wykształcenie rodziców) wpływają tylko na niektóre zachowania, albo ich wpływ przejawia się tylko w niektórych okresach. Zdarza się też, że oddziaływanie czynnika zmienia kierunek. Poczynione obserwacje skłaniają do przyjęcia wniosku, że wpływ poszczególnych determinant zmienia się w różnych sytuacjach.

\section{Literatura}

ANTONIDES G., Van RAAIJ W.F., 2003: Zachowanie konsumenta. Podręcznik akademicki, Wydawnictwo Naukowe PWN, Warszawa, s. 24.

BYWALEC CZ., 2007: Konsumpcja w teorii i praktyce gospodarowania, Wydawnictwo Naukowe PWN, Warszawa, s. 58.

BYWALEC CZ., 2009: Nowe wyzwania i wymiary konsumpcji we wspótczesnym świecie, Handel Wewnętrzny, 3(32), s.1-10.

BYWALEC CZ., 2010: Konsumpcja a rozwój gospodarczy i społeczny, Wydawnictwo C.H. Beck, Warszawa.

DULINIEC E., 1986: Postępowanie nabywców towarów konsumpcyjnych w krajach o gospodarce rynkowej, SGPiS, Warszawa, s. 303. 


\section{8}

Frequency of contacts with relatives or friends by sex and age, http://appsso.eurostat.ec.europa.eu/nui/show.do?dataset=yth_part_020\&lang=en (data dostępu: luty 2015).

Frequency of getting together with relatives or friends by sex and age, http://appsso.eurostat. ec.europa.eu/nui/show.do?dataset=yth_part_010\&lang=en (data dostępu: luty 2015).

GAJEWSKI S., 1997: Zachowanie się konsumenta a wspótczesny marketing, Wydawnictwo Uniwersytetu Łódzkiego, Łódź, s. 20-23.

GARBARSKI L. (red.), 2011: Marketing. Kluczowe pojęcia i praktyczne zastosowania, Polskie Wydawnictwo Ekonomiczne, Warszawa, s. 93.

GARBARSKI L., 1998: Zachowania nabywców, PWE, Warszawa, s. 21-37.

Individuals - frequency of internet use, http://appsso.eurostat.ec.europa.eu/nui/submitViewTableAction.do (data dostępu: luty 2015).

KIEŻEL E. (red.), 2000: Rynkowe zachowania konsumentów, Akademia Ekonomiczna w Katowicach, Katowice, s. 103-168.

KIEŻEL E. (red.), 2004: Racjonalność konsumpcji i zachowań konsumentów, PWE, Warszawa.

KRAMER J., 1997: Konsumpcja w gospodarce rynkowej, PWE, Warszawa, s. 78-82.

MRÓZ B., 2013: Konsument w globalnej gospodarce, Oficyna Wydawnicza SGH, Warszawa.

MRUK H., 2009: Konsument w gospodarce-ewolucja wiedzy o jego zachowaniach, Handel Wewnętrzny, 4-5, s. 43-51

OLEJNICZUK-MERTA A., 2001: Rynek młodych konsumentów w Polsce, DIFIN, Warszawa.

OLEJNICZUK-MERTA A., 2009: Młodzi konsumenci w procesach transformacji rynkowej, WAiP, Warszawa.

OLEJNICZUK-MERTA A., 2015: Konsumpcja czynnikiem innowacyjnego rozwoju. Konsumpcja i Innowacje, IBRKK, Warszawa, s. 10.

PATANAITTIKUL V., ONGKRUTRAKSA W., 2011: Thai youth and marketing communication in globalization age, International Journal of Management Cases, 13(4), s. 53-60.

PETER J.P., OLSON J.C., 2005: Consumer Behaviour and Marketing Strategy, 7th ed., Mc -GrawHill, NewYork.

Ratio of young people in the total population on 1 January by sex and age, http://appsso.eurostat.ec.europa.eu/nui/submitViewTableAction.do (data dostępu: listopad 2015).

Rocznik demograficzny 2015, Główny Urząd Statystycznym, Warszawa.

SCHIFFMAN L., O’CASS A., PALADINO A., CARLSON J. 2013: Consumer Behaviour, Pearson Education, Australia, s. 393.

SOLOMON M.R., 2006: Zachowania i zwyczaje konsumentów, One Press, Gliwice.

SOWA I., 2010: Nowe trendy w zachowaniach konsumentów, [W]: Konsument i jego zachowania na rynku europejskim, E. Kieżel (red.), PWE, Warszawa.

\section{Abstrakt}

Zachowania młodych konsumentów są przedmiotem zainteresowań ekonomistów już od kilku dziesięcioleci. Celem niniejszego artykułu jest wskazanie zmian, jakie zaszły w ostatnich 10 latach w zachowaniach młodych Polaków, zidentyfikowanie wybranych determinant ich zachowań oraz określenie sposobu oddziaływania tych czynników. Podstawę do wnioskowania na ten temat stanowią wyniki badań bezpośrednich przeprowadzonych wśród konsumentów z gru- 
py wiekowej 14-19 lat. Badania te miały miejsce kolejno w latach 2004, 2006 i 2014, a wykorzystaną w nich metodą była ankieta audytoryjna. Podstawowym wnioskiem z przeprowadzonych analiz jest stwierdzenie, że młodzi konsumenci sprawnie adaptują się do wyzwań współczesnego rynku. W ich zachowaniach wyraźnie można zauważyć przejawy wirtualizacji, serwicyzacji, a także trendu związanego ze zdrowym stylem życia. Jednocześnie trudno jest wskazać stałą grupę czynników determinujących zachowania młodych Polaków. Tylko niektóre determinanty (np. wiek czy płeć) równocześnie oddziałują na więcej niż jedno zachowanie, a ich wpływ jest stały (widoczny w kolejnych latach). Inne czynniki (np. miejsce zamieszkania czy wykształcenie rodziców) kształtują tylko wybrane zachowania lub też ich wpływ zmienia się w czasie. Zdarza się też, że oddziaływanie czynnika zmienia kierunek.

Słowa kluczowe: młodzi konsumenci, determinanty zachowań, zmiany zachowań, zachowania konsumentów

\section{Young Poles facing the challenges of the modern market: chosen behaviors and their determinants in years 2004-2014}

\section{Abstract}

Young consumers' behaviors are a subject of academic interest since several decades. The purpose of this article is to indicate the changes which occurred in behaviors of young Poles during the last 10 years, to identify chosen determinants of their behaviors and to specify a way of these determinants' influences. The basis for drawing conclusions on this topic are outcomes of field research conducted in a group of consumers aged from 14 to 19 . Those research projects took place in years 2004, 2006 and 2014, and with the use of auditorium questionnaire. The main finding of the analyses is that young consumers efficiently adapt to the challenges of the modern market. Symptoms of virtualization, servitization as well as a trend connected with healthy lifestyle can be observed. Simultaneously it is hard to indicate a constant set of determinants shaping behaviors of young Poles. Only chosen factors (e.g. age or sex) affect more than one type of behavior. Other factors, like place of living or parent's educational level, influence only single behaviors and this influence changes over time. It also happens that an influence of given factor changes its direction.

Key words: young consumers, determinants of behaviors, changes of behaviors, consumer behavior 
